\title{
Arrabidaea chica (HBK) Verlot: phytochemical approach, antifungal and trypanocidal activities
}

\author{
Wagner Luiz Ramos Barbosa, ${ }^{* 1}$ Lucianna do Nascimento Pinto, ${ }^{1}$ Etienne Quignard, ${ }^{1}$ José \\ Maria dos Santos Vieira, ${ }^{2}$ José Otávio Carrera Silva Jr., ${ }^{3}$ Sérgio Albuquerque ${ }^{4}$ \\ ${ }^{1}$ Laboratório de Fitoquímica, Faculdade de Farmácia, Universidade Federal do Pará, Campus Universitário do \\ Guamá, 66075-900 Belém-PA, Brazil, \\ ${ }^{2}$ Laboratório de Microbiologia, Faculdade de Farmácia, Universidade Federal do Pará, Campus Universitário do \\ Guamá, 66075-900 Belém-PA, Brazil, \\ ${ }^{3}$ Laboratório de Farmacotécnica, Faculdade de Farmácia, Universidade Federal do Pará, Campus Universitário \\ do Guamá, 66075-900 Belém-PA, Brazil, \\ ${ }^{4}$ Laboratório de Parasitologia, Faculdade de Ciências Farmacêuticas, Universidade de São Paulo, 14040903 \\ Ribeirão Preto-SP, Brazil
}

\begin{abstract}
RESUMO: “Arrabidaea chica (HBK) Verlot: abordagem fitoquímica, atividades tripanocida e antifúngica”. Arrabidaea chica (HBK.) Verlot (Bignoniaceae) popularmente, "Pariri”, é um arbusto escandente, distribuído do sul do México até a Guiana e Brasil central e é tradicionalmente indicado para tratar sintomas de inflamações e afecções da pele. Seu extrato etanólico foi quimicamente investigado e testado contra leveduras e fungos dermatófitos. A atividade tripanocida do mesmo extrato foi também avaliada. Este trabalho reporta o isolamento de três flavonóides, a inibição total do crescimento de Trichophyton mentagrophytes e um significante efeito tripanocida do extrato etanólico e de suas frações. Não foi detectada qualquer toxicidade aguda relevante, mesmo a uma dose de $1000 \mathrm{mg} / \mathrm{kg}$.
\end{abstract}

Unitermos: Arrabidaea chica, Bignoniaceae, flavonóides, Trichophyton mentagrophytes, atividade antifúngica, Trypanosoma cruzi, efeito tripanocida.

\begin{abstract}
Arrabidaea chica (HBK.) Verlot (Bignoniaceae) vernacular name "Pariri", is a climbing shrub, widespread from South Mexico to Guyana and central Brazil and is traditionally indicated to treat symptoms of inflammations and skin affections. Its ethanol extract was chemically investigated and tested against yeasts and dermatophytic fungi. The trypanocidal activity of the same extract was also evaluated. This work reports the isolation of three flavonoids, the total growth inhibition of Trichophyton mentagrophytes and a significant trypanocidal effect of the ethanol extract and its fractions. No relevant acute toxicity was detected even at a dose of $1000 \mathrm{mg} / \mathrm{kg}$.
\end{abstract}

Keywords: Arrabidaea chica, Bignoniaceae, flavonoids, Trichophyton mentagrophytes, antifungal activity, Trypanosoma cruzi, trypanocidal effect.

\section{INTRODUCTION}

Arrabidaea chica (HBK) Verlot, Bignoniaceae, is a scrambling shrub which occurs in tropical America, more particularly in the Amazon basin where it is called "Pariri", "Crajiru", "Carajuru” or "Carajiru” (Correa, 1931; van den Berg, 1993).

The leaves of the plant have been traditionally used by Brazilians Indians as dye in body painting for rituals and to protect the skin against the sunlight and to repel insect. Since the beginning of this century $A$. chica has been matter of chemical investigation that aimed to determine the composition of the dye, which was commercialised at that time (Chapman et al., 1927).

Nowadays $A$. chica is widely used in the popular medicine in Northern Brazil to treat blood dysfunction (anaemia, haemorrhage) and uterine inflammation being also indicated in hepatitis, haemorrhoids and skin affections. The plant is used as an infusion of fresh or dried leaves drunk continuously during one to three days replacing the usual diary beverage, or eventually used to bath external wounds (Barbosa et al., 2001).

Until today despite the large use and indication of $A$. chica very few is known about the chemical constitution of its leaves. The analysis of the dye performed decades ago (Chapman, 1927), the isolation of a flavone (Takemura, 1995) and of three anthocyanidins (Zorn et al., 2001) are the disposable chemical data about this species. Moreover, no pharmacological studies have been reported in the literature. More recently the content in phenolics and flavonoids in the leaf were determined, $\pm 10.2 \mathrm{mg} / \mathrm{g}$ and $0.06 \mathrm{mg} / \mathrm{g}$, respectively (Silva et al., 
2007). The total flavonoids content in tinctures $(30 \%$; $50 \%$ and $70 \%$ ethanol) and in aqueous extracts (infusion and decoction were also determined (Pinto, 2004) (Table $1)$.

Table 1. Total flavonoid content in preparations of A. chica.

\begin{tabular}{lc}
\hline \multicolumn{1}{c}{ Sample } & Conc. $(\mathrm{g} \%)$ \\
\hline Infusion & 1,300 \\
Decoct & 1,842 \\
Tincture 30\% & 4,866 \\
Tincture 50\% & 10,489 \\
Tincture 70\% & 14,969 \\
\hline
\end{tabular}

The present article reports the antifungal and trypanocidal activities detected in the ethanol extract of A. chica and in its fractions. The phytochemical analysis of the ethanol extract is also reported as the isolation of three flavonoids.

\section{MATERIAL AND METHODS}

\section{Plant material}

Leaves of Arrabidaea chica (HBK) Verlot were collected in Belém (State of Pará, Brazil). The plant material was identified by Dr. Maria Elisabeth van den Berg at the Museu Paraense Emílio Goeldi (MPEG), Belém, Pará, Brazil where a voucher specimen is deposited and registered under the number 150.701 (van den Berg, 1993).

\section{Preparation of extract and fractions}

Ethanol extract was prepared by maceration of $3.5 \mathrm{~kg}$ of fresh leaves for 5 days at room temperature. After filtration, the solvent was evaporated under reduced pressure to yield $101.0 \mathrm{~g}$ of a viscous red brown extract EtE - corresponding an yeld of $2.89 \% .50 \mathrm{~g}$ of the crude extract was then fractionated by column chromatography on silica gel (70-230 mesh ASTM, Merck $\left.{ }^{\mathrm{TM}}\right)$ using successively petroleum ether $100 \%$, petroleum etherhexane 50/50, hexane $100 \%$, hexane-dichloromethane $50 / 50$, dichloromethane $100 \%$, dichloromethanemethanol 50/50 and finally methanol $100 \%$ as eluent.

\section{Phytochemical analysis}

Chemical tests to detect the main classes of secondary metabolites were carried out using classical specific colour reactions (Mattos, 1988; Steinegger \& Hansel, 1992; Barbosa, 2001; Sena Filho et al., 2006; Migliato et al., 2007) and by spraying colour reagent on thin layer chromatograms (Wagner \& Bladt, 1996).

The isolation of a flavonoid was achieved by direct treatment of plant material with boiling $n$-hexane and the two others using usual chromatographic techniques.
They were analysed with adequate spectrometric methods in order to characterize their structures.

\section{Antifungal activity}

The antifungal activity of $A$. chica was assayed for four pathogenic fungi species using amphotericin $B$ (Sigma) at $0.25 \mathrm{mg} / \mathrm{mL}$ as a positive control and DMSOTris buffer 1:9 as a negative control. Tests were done in triplicate using the agar dilution method (van den Berghe \& Vlietinck, 1991; Sindambiwe et al., 1999; Longhini et al., 2007; Ostrosky et al., 2008). Clinical samples of Candida albicans, Aspergillus niger, Trichophyton rubrum and $T$. mentagrophytes were collected at the Clinical Laboratory (UFPA, State of Pará, Brazil) and identified by Prof. Dr. Jorge Pereira da Silva from the Faculdade de Farmácia, Universidade Federal do Pará. T. mentagrophytes is a frequent causal agent for several common skin infections in Brazil.

\section{Evaluation of the trypanocidal effect}

The assay was performed using the method described by Brener (1962) and Pizzolatti et al. (2008) against trypomastigotes, the blood circulating forms of the parasite. Trypomastigotes of T. cruzi (strain Y) were obtained from infected mice by collecting the blood at the top of the parasitemy ( $7^{\text {th }}$ day) by cardiac punction. The extract and the fractions were tested in triplicate at $4 \mathrm{mg} /$ $\mathrm{mL}$ and $2 \mathrm{mg} / \mathrm{mL}$ respectively using a range of $2 \times 10^{5}$ parasites. Parasites were counted in a hematocytometer after incubation at $4{ }^{0} \mathrm{C}$ for $24 \mathrm{~h}$ and the counts were compared with those without drug. The efficacy (percentage of lysis) was assessed comparing the results with crystal violet $(250 \mu \mathrm{g} / \mathrm{mL})$ used as baseline drug.

\section{RESULTS AND DISCUSSION}

Assays performed on crude ethanol extract using specific chemical reagent gave characteristic responses, as seen on the Table 2 .

\section{Isolation of $\mathbf{I}$}

From $112 \mathrm{~g}$ fresh leaves $35 \mathrm{mg}$ of (I) could be isolated by extraction with $n$-hexane under $6 \mathrm{~h}$ reflux. The substance was recovered by filtration after cooling. Yield 0,031\%. m.p. $203{ }^{\circ} \mathrm{C}\left(\mathrm{C}_{6} \mathrm{H}_{14}\right)$; UV max (MeOH): 256 (lg $\varepsilon$ $=0.97), 309(\lg \varepsilon=1.16), 482(\lg \varepsilon=1.06) ;(\mathrm{MeOH}-\mathrm{NaOH}$ 2M): 256, 310, 481; (MeOH-AlCl $)_{3}: 243,313,473$; (MeOH-AlCl$/ \mathrm{HCl})$ : 242, 313, 473; (MeOH-NaOAc): 245, 303, 561; (MeOH-NaOAC/ $\left.\mathrm{H}_{3} \mathrm{BO}_{3}\right)$ : 308, 468; IR bands $\left(\mathrm{NaCl}-\mathrm{CHCl}_{3}\right): 3185,2847,1721,1422,1257$, 1177, 1108, 1081, 907, $815 \mathrm{~cm}^{-1}$; ${ }^{1} \mathrm{H}-\mathrm{NMR}(300 \mathrm{MHz}$, $\left.\mathrm{CDCl}_{3}\right): \delta 3.90\left(3 \mathrm{H}, s, 7-\mathrm{OCH}_{3}\right), 4.10\left(3 \mathrm{H}, s, 3-\mathrm{OCH}_{3}\right)$, $6.55(1 \mathrm{H}, d, J=1.0 \mathrm{~Hz}, \mathrm{H}-8), 6.99(1 \mathrm{H}, d, J=8.0 \mathrm{~Hz}, \mathrm{H}-5)$, $7.02\left(2 \mathrm{H}, d d, J=8.0\right.$ and $2.0 \mathrm{~Hz}, \mathrm{H}-3^{\prime}$ and $\left.5^{\prime}\right), 7.88(2 \mathrm{H}$, 
Table 2. Metabolic classes detected in the ethanol extract of $A$. chica.

\begin{tabular}{|c|c|c|c|c|c|c|c|c|c|c|c|c|c|c|c|}
\hline $\begin{array}{c}\text { Metabolic } \\
\text { Class }\end{array}$ & $\begin{array}{l}\frac{\mathscr{Z}}{0} \\
\frac{0}{\pi} \\
\frac{\pi}{4}\end{array}$ & 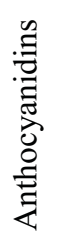 & 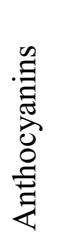 & 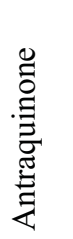 & 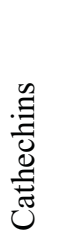 & 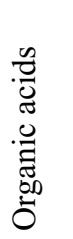 & 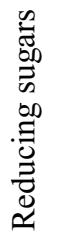 & $\begin{array}{l}\frac{n}{0} \\
\frac{0}{0} \\
\dot{0} \\
\dot{\omega}\end{array}$ & 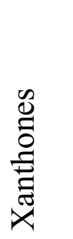 & 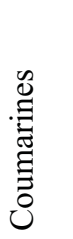 & 咅 & $\begin{array}{l}\frac{n}{0} \\
\stackrel{0}{0} \\
\frac{1}{\pi} \\
\frac{\pi}{I}\end{array}$ & 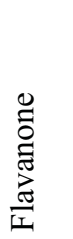 & 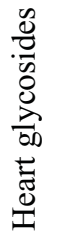 & 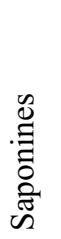 \\
\hline EtE & $(-)$ & $(+)$ & $(+)$ & $(+)$ & $(+)$ & $(+)$ & $(+)$ & $(+)$ & $(+)$ & ND & $(+)$ & $(+)$ & $(+)$ & I & ND \\
\hline
\end{tabular}

ND: Not determined; I: Only indication.

$d d, J=7.0$ and $2.0 \mathrm{~Hz}, \mathrm{H}-2$ ' and 6'), $8.01(1 \mathrm{H}, d d, J=8.0$ and $1.0 \mathrm{~Hz}, \mathrm{H}-6) ;{ }^{13} \mathrm{C}-\mathrm{NMR}\left(75 \mathrm{MHz}, \mathrm{CDCl}_{3}\right)$ : $\delta 176(\mathrm{C}-$ 4), 162 (C-7), 158 (C-D'), 156 (C-9), 139 (C-2), 135 (C5), 133 (split C-3), 127 (C 2' and 6'), 123 (C-1'), 118 (C-10), 114 (C-3' and 5'), 102 (C-6), 98 (C-8), 60 (OCH $_{3}$ at C-3), $55\left(\mathrm{OCH}_{3}\right.$ at C-7); $\mathrm{MS}(70 \mathrm{eV}) \mathrm{m} / \mathrm{z}: 300(12 \%)$, 299 (40), 298 (m+ 100), 297 (99), 296 (49), 295 (22), 283 (28), 269 (16), 256 (30), 255 (94), 254 (42), 253 (46), 240 (9), $237(8), 145(8), 116(8), 113(8), 98(8), 87(26), 86$ (10), 75 (8), $74(30), 73(14), 70(14), 69(34), 68(22), 58$ (12), 57 (30), 56 (12), 55 (32).

The infrared spectrum of I shows characteristic bands for flavonoids (Pretsch, et al., 1990) at the following wave number (in $\mathrm{cm}^{-1}$ ) 3185, 1422 for hydroxyl group; 2847 for methoxy group; 1721 for carbonyl group $\alpha, \beta-$ unsaturated; 1177 for $\gamma$-lactone, 1257 indicates ether group, 1108 and 1081 for methyl ether at $\mathrm{sp}^{2}-\mathrm{C}$. The bands at 907 and 815 correspond to 1,2,4-trisubstituted and $\mathrm{p}$-disubstituted benzene ring respectively .

Ultraviolet spectra in $\mathrm{MeOH}$ indicates a flavonol (Markham et al., 1975) as base structure for I. Addition of $\mathrm{NaOAc}$ produces a bathochromic shift of $99.4 \mathrm{~nm}$ of the band I, indicating the presence of a hydroxyl group at C-4'. The addition of $\mathrm{AlCl}_{3}$ e $\mathrm{AlCl}_{3} / \mathrm{HCl}$ cause hypsochromic shift of $8,8 \mathrm{~nm}$ e $13 \mathrm{~nm}$, and a bathochromic shift of $3,6 \mathrm{~nm}$. These values did not support the existence of groups like 4-keto-5-hydroxy, 4-keto-3-hydroxy and/or $o$-dihydroxylated rings.

The MS spectrum of I shows base and molecular peak at $\mathrm{m} / \mathrm{z} 298$, which corresponds to $\mathrm{C}_{17} \mathrm{H}_{14} \mathrm{O}_{5}$. The relevant signals are: $[\mathrm{m}-1]^{+}=297,[\mathrm{~m}]^{+}-\mathrm{CH}_{3}=283$, $\left[\mathrm{C}_{16} \mathrm{H}_{11} \mathrm{O}_{5}\right]^{+}-\mathrm{CO}=255$, and 145 , which corresponds to a Retro Diels Alder fragmentation of [m-3 $]^{+}$.

The ${ }^{13} \mathrm{C}-\mathrm{NMR}$ chemical shifts of the benzopyran system of I were attributed by comparison to partial structures already reported (Hattori et al., 1992, Ternai \& Markham, 1976, Wagner et al., 1976) and to calculated values (Pretsch et al., 1990). The sign due to C-3 is splitted probably because this position appear to stay under influence of the anisotropic effect of the $\mathrm{B}$ ring $(\Delta \delta$ $=0.057 \mathrm{ppm}$ ).

The ${ }^{1} \mathrm{H}-\mathrm{NMR}$ shows singlet at $3.90 \mathrm{ppm}$ and at $4.10 \mathrm{ppm}$ corresponding to two $-\mathrm{OCH}_{3}$ groups. The coupling of H-8, H-6 and H-5 form an ABX-system. H-5 appears at $8.01 \mathrm{ppm}, \mathrm{H}-6$ at $6.99 \mathrm{ppm}$ and $\mathrm{H}-8$, at 6.55 ppm. The coupling constants are $J_{1,2}=8.0 \mathrm{~Hz}$ and $J_{1,3}=1.0$ respectively. H-2'and $\mathrm{H}-6$ 'have the same chemical and magnetic environment, therefore show the same chemical shift 7 at $7.88 \mathrm{ppm}$. The same can be observed for H-3' and $\mathrm{H}-5$ '. They have $\delta=7,02 \mathrm{ppm}$. The coupling constant of $7.0 \mathrm{~Hz}$ corresponds to the ortho interaction of $\mathrm{H}-2$ ' and H-3'; and of H-5' and H-6'. For the coupling between H-2' and H-6'; and H-3' and H-5', could be observed a coupling constant of $1.0 \mathrm{~Hz}$.

These spectrometric data correspond to 4'-hydroxy-3,7-dimethoxyflavone (I).<smiles>COc1ccc2c(=O)c(OC)c(-c3ccc(O)cc3)oc2c1</smiles>

This substance has no data registered in the literature and also never was described in Arrabidaea genus before.

\section{Isolation of vicenin-2 and kaempferol}

An aliquot of $20 \mathrm{~g}$ EtE was treated successively with hexane, ethyl acetate and methanol. $800 \mathrm{mg}$ of the ethyl acetate fraction were submitted to column chromatography on $15 \mathrm{~g}$ silica gel RP18 (Merck ${ }^{\mathrm{TM}}$ ) using methanol/water (85:15) as eluent. Fractions 04 to 08 and 11 to 14 were analysed by TLC $\left(\mathrm{SiO}_{2} / \mathrm{CHCl}_{3}-\mathrm{CH}_{3} \mathrm{OH}\right.$ 90:10) and showed $\mathrm{Rf} 0.38$ and 0.56 respectively. They were combined to furnish $7 \mathrm{mg}$ vicenin-2 and $23 \mathrm{mg}$ kaempferol after purification. Vicenin-2 was purified by crystallisation from methanol/chloroform (1:1) and kaempferol by preparative TLC. The substances were characterised by spectrometric methods $\left({ }^{13} \mathrm{C}-\mathrm{NMR}\right.$, ${ }^{1} \mathrm{H}-\mathrm{NMR}$ and UV) (Pretsch et al., 1990) by comparison with published data (Xie et al., 2003; Wagner et al., 1976).

\section{Trypanocidal activity}


Table 3. Percent of lysis of trypomastigotes forms of stem Y of Trypanosoma cruzi toward eight fractions of ethanol extract of A. chica.

\begin{tabular}{c|c|c|c|c|c|c|c|c}
\hline Fractions & $\mathrm{F}_{2}$ & $\mathrm{~F}_{3}$ & $\mathrm{~F}_{4}$ & $\mathrm{~F}_{5}$ & $\mathrm{~F}_{6}$ & $\mathrm{~F}_{7}$ & $\mathrm{~F}_{8}$ & $\mathrm{~F}_{9}$ \\
\hline \% of lysis & 6.2 & 0.0 & 20.0 & 27.3 & 0.0 & 71.3 & 0.0 & 54.1 \\
\hline
\end{tabular}

EtE was tested at a concentration of $4 \mathrm{mg} /$ $\mathrm{kg}$ showing a significant activity on trypomastigote forms of T. cruzi, inducing $41 \%$ of cell lysis (Table 3 ). Chromatographic fractionation led to two fractions of higher activity, when tested at the concentration of $2 \mathrm{mg} /$ $\mathrm{mL}$ : the fraction $\mathrm{F} 7$, eluted with $\mathrm{CH}_{2} \mathrm{Cl}_{2} / \mathrm{MeOH}$ (50:50), produced lysis in $71 \%$ of the parasite cells, while the fraction $\mathrm{F} 9$, eluted with $\mathrm{MeOH} 100 \%$, produced $54 \%$ of lysis. Two others fractions, F4 and F5, both eluted by $\mathrm{CH}_{2} \mathrm{Cl}_{2} 100 \%$ still exhibited significant, even weak, activity with $20 \%$ and $28 \%$ of lysis, respectively.

This effect is already known for other Arrabidaea species and has been connected to the presence of triterpenoid acids from ursan and oleanan group (Leite et al., 1998) in the extract. The phytochemical approach also detected presence of compounds of that class in A. chica, however a possible role of naphtoquinones in the process of growth inhibition may not be discarded since it have been shown that the redox cycling of these substances, in T. cruzi, generates the highly cytotoxic hydroxyl radical. $\beta$-Lapachone, one of the first natural drugs tested has a minimum growth inhibitory concentration of $0.8 \mu \mathrm{g} / \mathrm{mL}$ against epimastigote forms (Oliveira et al., 1996).

\section{CONCLUSIONS}

After 14 days incubation EtE shows activity against $T$. mentagrophytes at a minimal inhibition concentration of $3.125 \mathrm{mg} / \mathrm{mL}$. No growth inhibition could be observed for the other three species tested. The activity against the same species has been reported for other genera of Bignoniaceae and was attributed to quinones (Ali et al., 1998; Saúde-Guimarães \& Faria, 2007). $\alpha$-and $\beta$-lapachone, two substances from this chemical class, have already been identified in Arrabidaea formosa (Rocha et al., 1998). Such results allow suggesting that quinones, detected in the phytochemical approach of Arrabidaea chica, could also be involved in the detected antifungal activity. Furthermore, other compounds, like flavonoids, detected in EtE, and described as having antifungal activity (Prasad et al., 2004) could also be involved in the activity reported here, since flavonoids are synthesized by plants in response to microbial infection. Thus, detection of the antifungal activity against $T$. mentagrophytes supports the traditional use of this plant validating the popular indications of $A$. chica to treat skin diseases. In addition, the results of the phytochemical approach show that $A$. chica produces compounds like anthocyanidins, catechins, organic acids, reducing sugars, steroids and xanthones (Table 2). Some of these chemical compounds (Cowan, 1999) can play a supplementary role in the antifungal activity of $A$. chica.

Finally, this work contributes to validate the popular indications of $A$. chica - for skin diseases - and reports an expected trypanocidal activity

\section{ACKNOWLEDGMENTS}

The authors are indebted to Prof. Dr. Jorge Pereira da Silva for fungi characterisation and express sincere thanks to Dr. Elisabeth van den Berg for the botanical characterisation of plant material. The authors are also indebted to the former "Superintendência para o Desenvolvimento da Amazônia" (SUDAM) for material support and to the Conselho Nacional de Desenvolvimento Científico e Tecnológico (CNPq) for the scientific fellowship to Dr. Etienne Quignard and for the grants to R.T. Ito and C.R.B. Romeiro (Laboratório de Fitoquímica).

WLR Barbosa would like to acknowledge Prof. Dr. Alaide Braga de Oliveira - UFMG for the support to the phytochemical investigations performed at her laboratory as a part of his Post-doctoral work.

\section{REFERENCES}

Ali RM, Hougton PJ, Hoo TS 1998. Anti-fungal Activity of some Bignoniaceae found in Malaysia. Phytother Res 12: 331-334.

Barbosa WLR (org.) 2001. Manual para análise fitoquímica e cromatográfica de extratos vegetais. Universidade Federal do Pará, Belém, www.propesp.ufpa.br/ revistaic/textos_didaticos.htm acessado 31st Oct 2007.

Brener Z 1962. Therapeutic activity a criterion of cure on mice experimentally infected with Trypanosoma cruzi. Rev Inst Med Trop São Paulo 4: 389-396.

Chapman E, Perkin AG, Robinson R 1927. The colouring matters of carajura. J Chem Soc 3015-3040.

Corrêa MP 1931. Dicionário das plantas úteis do Brasil e das espécies cultivadas. Vol. II. Rio de Janeiro: Ministério da Agricultura.

Cowan MM 1999. Plant products as antimicrobial agents. Clin Microbiol Rev 10: 564.

Hattori M, Huang XL, Che QM, Kawata Y, Tezuka Y, Kikuchi T, Nambe T 1992. 6-Hydroxykaempferol and its glycosides from Carthamus tinctorius petals. Phytochemistry 32: 4001-4004.

Leite JPV, Lombardi JA, Chiari E, Souza-Filho JD, Oliveira AB 1998. XV Simpósio de Plantas Medicinais do Brasil.

Longhini R, Raksa SM, Oliveira ACP, Svidzinski TIE, Franco SL 2007. Obtenção de extratos de própolis sob diferentes condições e avaliação de sua atividade antifúngica.

ev. Bras. Farmacogn. Braz J. Pharmacogn 18(4): Out./Dez. 2008 
Rev Bras Farmacogn 17: 388-395.

Markham KR, Mabry TJ 1975. The flavonoids - Part 1 (Editor J. B. Harborne, T. J. Mabry, H. Mabry). Chap. 2 and 3. New York: Academic Press.

Mattos FJA 1988. Introdução à fitoquímica experimental. Fortaleza: Edições UFC

Migliato KF, Moreira RRD, Mello JCP, Sacramento LVS, Corrêa MA, Salgado HRN 2007. Controle da qualidade do fruto de Syzygium cumini (L.) Skeels. Rev Bras Farmacogn 17: 94-101.

Oliveira AB, Takahashi JA, Lombardi JA, Jacome RLP, Boaventura MAD, Chiari E 1996. VIII Simpósio Latino-americano de Farmacobotânica.

Ostrosky EA, Mizumoto MK, Lima MEL, Kaneko TM, Nishikawa SO, Freitas BR 2008. Métodos para avaliação da atividade antimicrobiana e determinação da concentração mínima inibitória (CMI) de plantas medicinais. Rev Bras Farmacogn 18: 301-307.

Pinto LN 2004. Levantamento etnofarmacêutico dos fitoterápicos tradicionais utilizados no municipio de Cametá e análise de Arrabidaea chica (HBK) Verlot. Belém, 77p. Monografia de Especialização, Faculdade de Farmácia, Universidade Federal do Pará.

Pizzolatti MG, Mendes BG, Cunha Jr A, Soldi C, Koga AH, Eger I, Grisard EC, Steindel M 2008. Trypanocidal activity of coumarins and styryl-2-pyrones from Polygala sabulosa A.W. Bennett (Polygalaceae). Rev Bras Farmacogn 18: 177-182.

Prasad NR, Anandi C, Balasubramanian S, Pugalendi KV 2004. Antidermatophytic activity of extracts from Psoralea corylifolia (Fabaceae) correlated with the presence of a flavonoid compound. J Ethnopharmacol 91: 21-24.

Pretsch E, Seibl J, Simon W, Clerc T 1990. Tabellen zur strukturaufklaerung organischer verbindungen mit spektroskopischen methoden, $3^{\text {rd }}$ ed. Berlin: Springer Verlag.

Rocha AD, Barroso ACS, Braga FC, Oliveira AB 1998. XV Simpósio de Plantas Medicinais do Brasil.

Saúde-Guimarães DA, Faria AR 2007. Substâncias da natureza com atividade anti-Trypanosoma cruzi. Rev Bras Farmacogn 17: 455-465.

Sena Filho JG, Melo JGS, Saraiva AM, Gonçalves AM, Psiottano MNC, Xavier HS 2006. Antimicrobial activity and phytochemical profile from the roots of Lippia alba (Mill.) N.E. Brown. Rev Bras Farmacogn 16: 506-509.

Silva EM, Souza JNS, Rogez H, Rees JF, Larondelle Y 2007. Antioxidant activities and polyphenol contents of fifteen selected plant species from the Amazonian region. Food Chem 101: 1012-1018.

Sindambiwe JB, Calomme M, Cos P, Tottlé J, Pieters L, Vlietinck A, van den Berghe DA 1999. Screening of seven selected Rwandan medicinal plants for antimicrobial and antiviral activities. $J$ Ethnopharmacol 65: 71-77.

Steinegger E, Hänsel R 1992. Pharmakognosie, 5th ed. Berlin: Springer Verlag.

Takemura OS, Ilnuma M, Tosa H, Miguel OG, Moreira EA, Nozawa Y 1995. A flavone from leaves of Arrabidaea chica f. cuprea. Phytochemistry 35: 1299-1300.

Ternai B, Markham KR 1976. Carbon-13 NMR studies of flavonoids I. Flavones and flavonols. Tetrahedron 32: 565-569.

van den Berghe DA, Vlietinck AJ 1991. Screening methods for antibacterial and antiviral agents from higher plants. Methods Plant Biochem 6: 47-49.

van den Berg ME 1993. Plantas medicinais na Amazônia $2^{\text {nd }}$ Ed., Belém: CNPq/ Programa Trópico Úmido.

Wagner H, Bladt S 1996. Plant drug analysis 2nd ed. Heildelberg: Springer Verlag.

Wagner H, Vedantha MC, Sonnenbichler J 1976. ${ }^{13} \mathrm{C}-\mathrm{NMR}-$ spektren natuerlich vorkommender flavonoide. Tetrahedron Lett 21: 1799-1802.

Xie C, Veitch N, Houghton PJ, Simmonds MSJ 2003. Flavone C-glicosides from Viola yedoensis Makino. Chem Pharm Bull 51: 1204-1207.

Zorn B, Garcia-Pineres AJ, Castro V, Murillo R, Mora G, Merfort I 2001. 3-Desoxyanthocyanidins from Arrabidaea chica. Phytochemistry 56: 831-835. 